Article

\title{
Combination of Marker-Assisted Backcross Selection of Yr59 and Phenotypic Selection to Improve Stripe Rust Resistance and Agronomic Performance in Four Elite Wheat Cultivars
}

\author{
Min Zhang ${ }^{1,+}$, Taohong Fang ${ }^{1,+}$, Xinli Zhou ${ }^{1, * \mathbb{D}}$, Xianming Chen ${ }^{2}$, Xin Li ${ }^{1}$, Junyan Feng ${ }^{3}$, Suizhuang Yang ${ }^{1}$ \\ and Zhensheng Kang 4 (D)
}

1 Wheat Research Institute, School of Life Sciences and Engineering, Southwest University of Science and Technology, Mianyang 621000, China; maggie_zm2893@sina.com (M.Z.); zrd_479@sina.com (T.F.); sadoneli@gmail.com (X.L.); yangszh@126.com (S.Y.)

2 USDA-ARS, Wheat Health, Genetics, and Quality Research Unit, Department of Plant Pathology, Washington State University, Pullman, WA 99164-6430, USA; xianming@wsu.edu

3 Biotechnology and Nuclear Technology Research Institute, Sichuan Academy of Agricultural Sciences, Chengdu 610066, China; junyanfeng@live.cn

4 State Key Laboratory of Crop Stress Biology in Arid Areas, College of Plant Protection, Northwest A\&F University, Xianyang 712100, China; kangzs@nwsuaf.edu.cn

* Correspondence: eli6951@sina.com

+ These authors contributed equally to this work.

Citation: Zhang, M.; Fang, T.; Zhou, X.; Chen, X.; Li, X.; Feng, J.; Yang, S.; Kang, Z. Combination of

Marker-Assisted Backcross Selection of Yr59 and Phenotypic Selection to Improve Stripe Rust Resistance and Agronomic Performance in Four Elite Wheat Cultivars. Agronomy 2022, 12, 497. https://doi.org/10.3390/ agronomy12020497

Academic Editor: José Miguel Soriano

Received: 7 January 2022

Accepted: 10 February 2022

Published: 17 February 2022

Publisher's Note: MDPI stays neutral with regard to jurisdictional claims in published maps and institutional affiliations.

Copyright: (c) 2022 by the authors. Licensee MDPI, Basel, Switzerland. This article is an open access article distributed under the terms and conditions of the Creative Commons Attribution (CC BY) license (https:// creativecommons.org/licenses/by/ $4.0 /)$.

\begin{abstract}
In this study, we successfully introgressed and validated $Y_{r} 59$ into four elite wheat cultivars, Jimai 22, Chuanmai 42, Zhengmai 9023 and Xinmai 26 through marker-assisted backcross selection. Used as female parents, these four cultivars were crossed with wheat line PI 660061 (Yr59). After two backcrosses and marker-assisted selection, the progenies were selfed and advanced to the $\mathrm{BC}_{2} \mathrm{~F}_{4}$ generation. A total of $123 \mathrm{BC}_{2} \mathrm{~F}_{4}$ lines were selected based on agronomic traits and stripe rust resistance, and their $\mathrm{BC}_{2} \mathrm{~F}_{5}$ and $\mathrm{BC}_{2} \mathrm{~F}_{6}$ progenies were further evaluated for stripe rust resistance and agronomic traits. Seven markers linked with relevant genes, including Xbarc32, Xwgp5175, Xwmc557 and Xcfa2040 linked with Yr59; Xwmc658 with YrJ22; WE173 and Xbarc181 with Yr26, were used to genotype the breeding lines. A total of 109 introgression lines with positive markers for $Y r 59$ were identified for further stripe rust and agronomic trait evaluation. Finally, 16 lines had higher levels resistance to stripe rust, and similar or superior agronomic traits compared to their parents were obtained. These lines can be released as new cultivars for various regions after regional tests and also can be used as resistance stocks for regional breeding programs to develop new cultivars with adequate and durable resistance to stripe rust.
\end{abstract}

Keywords: wheat stripe rust; high-temperature adult-plant (HTAP) resistance; marker-assisted selection; agronomic traits

\section{Introduction}

Wheat is one of the most widely cultivated cereal crops in the world and a staple food for approximately $40 \%$ of the world's populations, providing over $20 \%$ of the calories, $25 \%$ of the protein and nearly $55 \%$ of the carbohydrate intake of humans [1]. The growing human population is posing a concomitant upsurge in foodstuff demand. Therefore, wheat cultivars with high yield and high quality are crucial for global food safety. Certain biotic and abiotic stresses limit the realization of the full genetic potential of modern wheat cultivars, of which stripe rust, caused by Puccinia striiformis Westend. f. sp. tritici Erikss. Pst, is one of the most important pathogens threatening wheat production [2,3]. It is reported that the grain yield and quality loss of resistant wheat varieties were less than that of the susceptible under wheat stripe rust infection environment [4]. Fungicides can be used to 
reduce yield losses caused by stripe rust, but the use of fungicides adds cost to production and may be harmful to the users and the environment. The best approach of stripe rust control is breeding stripe rust-resistant cultivars.

Developing a wheat cultivar through a conventional approach usually takes 7 to 12 years. Marker-assisted selection (MAS) can accelerate the breeding process [5,6]. The MAS breeding method has been wildly used in the improvement of many crops, for instance, barley [7], wheat [8,9], maize [10], peanut [11,12], rice [13], tea [14]. Different types of markers can be used in MAS. Wheat scientists are still using simple sequence repeat (SSR) markers in molecular mapping and MAS, for reproducibility, multi-allelic nature, co-dominant inheritance, good genome coverage and robust amplification and availability of SSR for many specific traits [15]. For example, Vishwakarma et al. [16] used SSR markers to improve grain protein content and grain weight in Indian bread wheat. Yaniv et al. [17] used a set of polymorphic SSR markers to introgress $Y r 15$ into wheat lines for improving stripe rust resistance. Mallick et al. [18] used markers linked to Lr19/Sr25 and Yr10 to combine multiple rust resistances in wheat. Randhawa et al. [19] used SSR markers in transferring stripe and stem rust resistance genes $Y r 51, Y r 57, S r 22, S r 26$ and Sr50 into four wheat cultivars. In addition, technologies such as high-throughput arrays and nextgeneration DNA sequencing (NGS) offer other choices of markers and single nucleotide polymorphisms (SNPs), for instance, to study the distribution of chromosomal segments, discovery of new genes and MAS $[20,21]$. With the characteristic of high-abundance, highthroughput analysis and relatively low genotyping error rates and especially the ability to be transformed to another form of markers in an excellent conversion rate range from $50 \%$ to $97 \%$, SNP markers may open the innovation of research gate [22-24]. Kompetitive Allele Specific PCR (KASP) genotyping, an application of SNP marker, has been employed in wheat mapping and breeding. Mu et al. [25] developed KASP markers for stripe rust resistance quantitative trait locus (QTL) QYrcen.nwafu-7BL, and Neelam et al. [26] developed KASP markers for leaf rust resistance gene Lr21. Using SSR and KASP markers, Qie et al. [27] pyramided tightly linked stripe rust resistance genes Yr15 and Yr64 into new wheat germplasm lines. Kaur et al. [28] developed KASP assays for improving wheat resistance or tolerance to various biotic and abiotic stresses and agronomic, physiological and quality traits.

There are two types of resistance to stripe rust: all-stage resistance (ASR, also called seedling resistance) and adult-plant resistance (APR, including high-temperature adultplant (HTAP) resistance) $[29,30]$. All-stage resistance is expressed at all growth stages and can be easily detected at the seedling stage [29,31,32]. It is generally race-specific, qualitatively inheritance and readily overcome by newly virulent races. Wheat cultivars containing this type of resistance alone will become susceptible within a few years of release [31]. New virulent races are selected by directional selection pressure from growing cultivars with race-specific resistance $[33,34]$. By contrast, adult-plant resistance or HTAP resistance is expressed at post-seedling growth stage, is non-race-specific and contains durable resistance $[29,31,35,36]$. Many genes or QTL for HTAP resistance to stripe rust have been mapped, and markers linked to these genes have been developed. For example, Yr59, a HTAP gene reported by Zhou et al. [36], was located on long arm of chromosome 7B and flanked by markers Xwgp5175 and Xbarc32 about 2.1 cM in distance [36]. The constant evolvement of virulent Pst races continues circumvents race-specific resistance in wheat cultivars, resulting significant yield losses. It is urgent to introgress APR genes into elite cultivars to combat stripe rust.

So far, 83 officially named genes and at least 300 QTL have been reported, and useful molecular markers have been developed for some of them [37,38]. Over 60 of the stripe rust resistance genes or QTL have been intentionally used in wheat breeding [39], for instance, Yr5 and Yr15 combined in several wheat cultivars (reviewed by Wang and Chen 2017), Yr15 and Yr64 by Qie et al. [27], Yr15 by Kaur et al. [40], Yr26 by Zheng et al. [41], Yr48 by Yang et al. [42], and QYr.nafu-2BL and QYr.nafu-3BS by Hu et al. [43]. 
The present study was conducted to introgress HTAP resistance gene $Y$ r59 from PI 660061 into four main Chinese elite cultivars from different wheat production regions of China through MAS. Progeny lines were also selected through evaluation of several agronomic traits. The selected lines were demonstrated to have combinations of improved stripe rust resistance and desirable agronomic traits. These lines can be used for further yield and adaptation tests for releasing as new cultivars to be grown in various wheat production regions and/or use as genetic stocks for developing new wheat cultivars with adequate levels of durable resistance to stripe rust.

\section{Materials and Methods}

\subsection{Plant Material}

Four elite wheat cultivars, Chuanmai 42 (CM42), Jimai 22 (JM22), Zhengmai 9023 (ZM9023) and Xinmai 26 (XM26), were used as recurrent parents in this study. These cultivars were selected because they have excellent agronomic traits and have been widely planted in their corresponding regions covering the major wheat growing regions in China [44-47]. CM42, a spring wheat cultivar developed from the cross of Syn-CD768/ SW3243//C6415 by the Crop Research Institute of Sichuan Academy of Agricultural Sciences, has high yield potential, disease resistance and good quality and has been widely grown in Sichuan and other provinces in southwestern China. It has Yr26 [48,49], a stripe rust resistance gene recently becoming ineffective to new races virulent. JM22, a facultative winter cultivar developed by Crop Research Institute, Shandong Academy of Agricultural Sciences and widely grown in Hebei and other provinces in the northern wheat growing region of China, contains YrJ22 and PmJM22, providing only a moderate level of stripe rust resistance [50,51]. ZM9023, a weak spring cultivar developed by Wheat Research Institute of Henan Academy of Agricultural Sciences, has high salt tolerance, superior gluten quality and Fusarium head blight resistance (QFhb.7D) [52,53]; it was extensively planted in Henan and other provinces. XM26, developed by Xinxiang Henan Academy of Agricultural Sciences, is a facultative winter wheat variety widely grown in Henan provinces in the Huang Huai Hai wheat growing region. All these four wheat cultivars have high capacity to tolerate local biotic and abiotic stresses but either lost their resistance or do not have adequate resistance to stripe rust under the prevalence of CYR34, a new virulent race found in 2008 in Sichuan [54,55]. PI 178759 is a spring Iraq landrace with Yr59 for non-race-specific HTAP resistance to stripe rust [36]. PI 660061, a wheat germplasm line transferred from PI 178759, has excellent resistance to stripe rust and relatively better agronomic traits compared to PI 178759 [56] and was used as the donor parent of Yr59 in crosses with the four Chinese cultivars.

The four crosses (CM42/PI660061, JM22/PI660061, ZM9023/PI660061 and XM26/PI660061) were made in 2014. Two-round backcrosses were completed during 2015-2016, and the $\mathrm{BC}_{1} \mathrm{~F}_{1}$ and $\mathrm{BC}_{2} \mathrm{~F}_{1}$ plants were selected for the presence of molecular markers for $Y r 59$. The selected $\mathrm{BC}_{2} \mathrm{~F}_{1}$ plants were selfed and advanced to the $\mathrm{BC}_{2} \mathrm{~F}_{6}$ generation from 2016 to 2021 in the fields. Seeds of $\mathrm{BC}_{2} \mathrm{~F}_{2}$ to $\mathrm{BC}_{2} \mathrm{~F}_{3}$ were bulk-harvested for each cross to keep all possible genotypes. Plants with good stripe rust resistance and agronomic traits were visually selected from the $\mathrm{BC}_{2} \mathrm{~F}_{4}$ generation to produce individual $\mathrm{BC}_{2} \mathrm{~F}_{5}$ lines. The $\mathrm{BC}_{2} \mathrm{~F}_{5}$ and $\mathrm{BC}_{2} \mathrm{~F}_{6}$ lines were tested with markers for $\mathrm{Yr}_{r} 59$ to selected homozygous resistant lines. The tests before 2017 were conducted in Yangling (34.292N, 108.077E) of Shanxi province, and the tests during 2018-2021 were mainly conducted in Mianyang (31.682N, 104.663E) of Sichuan province.

\subsection{Phenotyping for Stripe Rust Reaction and Agronomic Traits in the Fields}

Phenotypic evaluation and selection were performed on the $\mathrm{BC}_{2} \mathrm{~F}_{4}, \mathrm{BC}_{2} \mathrm{~F}_{5}$ and $\mathrm{BC}_{2} \mathrm{~F}_{6}$ generations. A total of 123 individual plants were selected from the $\mathrm{BC} 2 \mathrm{~F} 4$ generation of all crosses to harvest $\mathrm{BC}_{2} \mathrm{~F}_{5}$ seeds based on medium plant height, high stripe rust resistance and good yield-related traits. The $\mathrm{BC}_{2} \mathrm{~F}_{5}$ seeds were planted, and their plants were evaluated for stripe rust resistance and agronomic traits in Mianyang during the 2019-2020 
growth season, and the $\mathrm{BC}_{2} \mathrm{~F}_{6}$ line were planted and evaluated in the experimental fields of both Mianyang and Yangling during the 2020-2021 season. The field experiments were conducted as in a randomized complete block design with three replications. Approximately 60-80 seeds each line were planted in a row of $2 \mathrm{~m}$ with $25 \mathrm{~cm}$ between rows. The parents and Mingxian 169 (MX169), a stripe rust-susceptible cultivar used as control, were planted after every 20 rows and around the field. Mianyang, where Pst can over-winter and over-summer, is one of the major stripe rust epidemic areas in China, and stripe rust occurs naturally with no need of artificial inoculation [57]. In Yangling, where severe stripe rust occurs less frequently than Mianyang, the field was inoculated with a mix of urediniospores of Pst races CYR32, CYR33 and CYR34 when flag leaves were emerging.

Stripe rust infection type (IT) was assessed based on the 0-9 scale [58], and disease severity (DS) was recorded as the percentage of infected leaf area for each line using a modified scale from Peterson [59]. Both IT and DS data were collected when the susceptible control MX169 exhibited nearly 80\% severities around the flowering stage and again after a week. The mean IT and DS scores of the plants and between the two records were calculated and used to rate each line. IT 0-3, 4-6 and 7-9 were considered resistant, intermediate and susceptible, respectively. The DS data were also considered in the line selections.

Desirable agronomic traits such as PH (plant height), NS (number of spikes), SL (spike length), GNS (grain number per spike) and TGW (thousand-grain weight) were determined to select lines. The PH was measured from the ground to the top of the spike except awn after the milk stage. The NS, SL and GNS of each plant were counted after maturity or harvest. Two hundred seeds were randomly sampled three times and weighed for each line, and TGW were calculated as the mean of the three weighs.

\subsection{Molecular Marker Genotyping}

Molecular markers linked to Yr59, namely Xbarc32, Xwgp5175, Xwmc557 and Xcfa2040, were used to select plants carrying the $Y$ r59 from a previous study [36]. The genetic distances between Xbarc32 and Xwgp5175, Xwmc557 and Xcfa2040 are both 2.1 cM, and Yr59 is located in the Xbarc32 and Xwgp5175 interval. Xwgp5175 linked to Xwmc557 with genetic distance of $2.2 \mathrm{cM}$. Of these markers, Xbarc32, which is closest to the resistance allele, was used to select $\mathrm{F}_{1}, \mathrm{BC}_{1} \mathrm{~F}_{1}$ and $\mathrm{BC}_{2} \mathrm{~F}_{1}$ plants containing $Y r 59$. Markers Xbarc181 and WE173, which are linked to $Y_{r} 26$ with genetic distances of $6.7 \mathrm{cM}$ and $1.4 \mathrm{cM}$ in CM42, respectively [49], were used to detect $\mathrm{BC}_{2} \mathrm{~F}_{5}$ lines containing $Y$ r26 in the cross of CM42///CM42//CM42/PI660061. Xwmc658, which is linked to YrJ22 with genetic distance of $1.0 \mathrm{cM}$ in JM22 [50], was used to detect $Y r J 22$ in $\mathrm{BC}_{2} \mathrm{~F}_{5}$ lines of JM22/ / /JM22/ /JM22/PI660061. SSR markers Xbarc32 and Xwmc557 were tested by polyacrylamide gel electrophoresis (PAGE) at Southwest University of Science and Technology. Markers Xwgp5175, Xcfa2040, Xbarc181, WE173 and Xwmc658 were detected using Fragment Analyzer system at Biotechnology and Nuclear Technology Research Institute, Sichuan Academy of Agricultural Sciences. The sequencies of these primers and annealing temperatures are listed in Table 1. 
Table 1. Sequence and amplification information for simple sequence repeat (SSR) markers linked to Yr59, Yr26 and YrJ22.

\begin{tabular}{|c|c|c|c|c|}
\hline Marker & Primer Sequence & $\operatorname{Tm}\left({ }^{\circ} \mathrm{C}\right)$ & Linked to $Y_{r}$ Gene & References \\
\hline Xbarc32 & $\begin{array}{l}\text { GCGTGAATCCGGAAACCCAATCTGTG } \\
\text { TGGAGAACCTTCGCATTGTGTCATTA }\end{array}$ & 60.5 & Yr59 & {$[36,60]$} \\
\hline Xwgp5175 & $\begin{array}{l}\text { GGAGGCTTAGGGAAG } \\
\text { TGGTAGGTCCTTGTA }\end{array}$ & 49.0 & Yr59 & {$[36,60]$} \\
\hline Xwmc557 & $\begin{array}{c}\text { GGTGCTTGTTCATACGGGCT } \\
\text { AGGTCCTCGATCCGCTCAT }\end{array}$ & 57.6 & Yr59 & {$[36,61]$} \\
\hline Xcfa2040 & $\begin{array}{l}\text { TCAAATGATTTCAGGTAACCACTA } \\
\text { TTCCTGATCCCACCAAACAT }\end{array}$ & 52.2 & Yr59 & {$[36,60]$} \\
\hline Xwmc658 & $\begin{array}{l}\text { CTCATCGTCCTCCTCCACTTTG } \\
\text { GCCATCCGTTGACTTGAGGTTA }\end{array}$ & 57.6 & YrJ22 & {$[50,60]$} \\
\hline WE173 & $\begin{array}{l}\text { GGGACAAGGGGAGTTGAAGC } \\
\text { GAGAGTTCCAAGCAGAACAC }\end{array}$ & 58.0 & Yr26 & {$[49,60]$} \\
\hline Xbarc181 & $\begin{array}{c}\text { CGCTGGAGGGGGTAAGTCATCAC } \\
\text { CGCAAATCAAGAACACGGGAGAAAGAA }\end{array}$ & 58.0 & Yr26 & {$[49,60]$} \\
\hline
\end{tabular}

Genomic DNA was extracted from fresh seedling leaves using the Cetyltrimethylammonium bromide (CTAB) method with slight modifications [62]. DNA quality and quantity were checked using Nanodrop ND-1000 spectrophotometer (Nanodrop Technologies, Wilmington, NC, USA), and the stock DNA was diluted to $50 \mathrm{ng} / \mu \mathrm{L}$ for use as template in polymerase chain reaction (PCR).

The PCR reaction for each DNA sample was performed in a $10 \mu \mathrm{L}$ mixture containing $2 \mu \mathrm{L}(50 \mathrm{ng} / \mu \mathrm{L})$ DNA template, $1 \mu \mathrm{L} 10 \times$ PCR buffer (containing $\mathrm{mg}^{2+}$ ), $0.8 \mu \mathrm{L} 2.5 \mathrm{mM}$ of dNTP, $1 \mu \mathrm{L}(2 \mu \mathrm{M})$ of each primer solution, $0.2 \mu \mathrm{L}$ Taq DNA polymerase solution (2.5 unit $/ \mu \mathrm{L}$ ) and $4 \mu \mathrm{L}$ sterilized double distilled water $\left(\mathrm{ddH}_{2} \mathrm{O}\right)$. The PCR amplification was performed as follows: pre-denaturation at $95^{\circ} \mathrm{C}$ for $3 \mathrm{~min}$; followed by 40 cycles of $95.0^{\circ} \mathrm{C}$ for $30 \mathrm{~s}$ for denaturation, $45^{\circ} \mathrm{C}$ or $65^{\circ} \mathrm{C}$ for $30 \mathrm{~s}$ for annealing depending upon primers, and $72{ }^{\circ} \mathrm{C}$ for $30 \mathrm{~s}$ for extension; and final $72{ }^{\circ} \mathrm{C}$ for $5 \mathrm{~min}$ for incubation. A mixture of $4 \mu \mathrm{L}$ of the amplification products and $6 \mu \mathrm{L}$ denaturation buffer were loaded in a $6 \%$ polyacrylamide gel (Beijing Solarbio Science \& Technology Co., Ltd. Beijing, China) [63] or $5 \mu \mathrm{L}$ of the amplification products mixed with $19 \mu \mathrm{L}$ TE buffer were separated using Fragment Analyzer (Agilent Technology Co., Ltd. Santa Clara, California, USA). The fluorescence signals of PCR products and genescan-500 molecular weight standard were automatically recorded by the gene analyzer.

\subsection{Statistical Analysis}

Phenotypic data of stripe rust and agronomic traits were analyzed using software GraphPad Prism Version 8.0.2. Histograms were generated using the Grouped function. The unpaired $t$-test was used to compare the means of the traits among wheat lines. A $p$-value of $<0.05$ was considered significant.

\section{Results}

\subsection{Marker-Assisted Backcrossing (MABC)}

Crossing, backcrossing and selfing of each cross were conducted as in the scheme illustrated in Figure 1. The numbers of selected plants in each generation are given in Table 2. Forty-three " $\mathrm{F}_{1}$ " seeds were harvested from the four crosses. Thirty three true $\mathrm{F}_{1}$ plants were identified to contain positive Xbarc32, consisting of eight from CM42/PI660061, nine from JM22/PI660061, seven from ZM9023/PI660061 and nine from XM26/PI660061. These true $\mathrm{F}_{1}$ plants were used as male parents to make the first-round backcross with their recurrent parents CM42, JM22, ZM9023 or XM26. About $50 \mathrm{BC}_{1} \mathrm{~F}_{1}$ seeds were harvested from each cross and planted in the greenhouse. DNA extraction and marker testing were performed in the same with $\mathrm{F}_{1}$ plants. After testing with $\mathrm{Xbarc32}, 23 \mathrm{BC}_{1} \mathrm{~F}_{1}$ plants, including 6 from 
$13 \mathrm{CM} 42 / / \mathrm{CM} 42 / \mathrm{PI} 660061,7 \mathrm{BC}_{1} \mathrm{~F}_{1}$ plants from $15 \mathrm{JM} 22 / / \mathrm{JM} 22 / \mathrm{PI} 660061,4 \mathrm{BC}_{1} \mathrm{~F}_{1}$ plants from $10 \mathrm{ZM9023//ZM9023/PI660061} \mathrm{and} 6 \mathrm{BC}_{1} \mathrm{~F}_{1}$ plants from 12 XM26/ /XM26/PI660061, were found heterozygous for the marker locus. These $\mathrm{BC}_{1} \mathrm{~F}_{1}$ plants were used to make the second-round backcross. A total of $98 \mathrm{BC}_{2} \mathrm{~F}_{1}$ seeds were obtained and sown in the field in Yangling in 2015 and selfed. After testing with Xbarc32, $49 \mathrm{BC}_{2} \mathrm{~F}_{1}$ plants were found to have the marker, including 12 from CM42/ / CM42//CM42/PI660061, 16 from JM22 / / /JM22 / /JM22/PI660061, 10 from ZM9023// /ZM9023//ZM9023/PI660061 and 11 from XM26// /XM26//XM26/PI660061. $\mathrm{BC}_{2} \mathrm{~F}_{2}$ seeds were harvested from the $49 \mathrm{BC}_{2} \mathrm{~F}_{1}$ plants, planted in fields, selfed and advanced to the $\mathrm{BC}_{2} \mathrm{~F}_{6}$ generation. In the $\mathrm{BC}_{2} \mathrm{~F}_{4}$ generation, 123 plants were selected based on their stripe rust reaction and agronomic traits, and the seeds were individually harvested to form $123 \mathrm{BC}_{2} \mathrm{~F}_{5}$ lines, consisting of 28 from CM42///CM42//CM42/PI660061, 43 from JM22///JM22//JM22/PI660061, 19 from ZM9023// /ZM9023//ZM9023/PI660061, and 33 from XM26///XM26//XM26/PI660061. The selected $\mathrm{BC}_{2} \mathrm{~F}_{4}$ plants had intermediate to resistant reactions to stripe rust, $80-110$ $\mathrm{cm}$ plant height, and kernel-full spikes. After the selected $\mathrm{BC}_{2} \mathrm{~F}_{5}$ lines with two markers (Xbarc32, Xwmc557) and their $\mathrm{BC}_{2} \mathrm{~F}_{6}$ lines with four markers (Xbarc32, Xwgpp5175, Xwmc557 and Xcfa2040), which produced generally consistent results with the disease ratings in the fields of the two locations and two years, 109 lines were selected as resistant to stripe rust with $Y r 59$ and desirable agronomic traits. The 109 lines included 28 from CM42///CM42//CM42/PI660061, 39 from JM22///JM22//JM22/PI660061, 16 from ZM9023// /ZM9023/ /ZM9023/PI660061 and 26 from XM26// /XM26/ /XM26/PI660061. In addition, markers Xbarc181 and WE173 linked to $Y r 26$ were used to detect the genes in the selected lines from CM42///CM42//CM42/PI660061, and marker WMC658, linked to YrJ22, was used to detect the gene in the selected lines from XM26/ / XM26/ /XM26/PI660061, resulting 15 lines from CM42///CM42//CM42/PI660061 with Yr26 and 27 lines with YrJ22 from the crosses, respectively. Among the 109 lines, 15 had both $Y r 59$ and $Y r 26$ and 23 had both Yr59 and YrJ22 (Table 2).

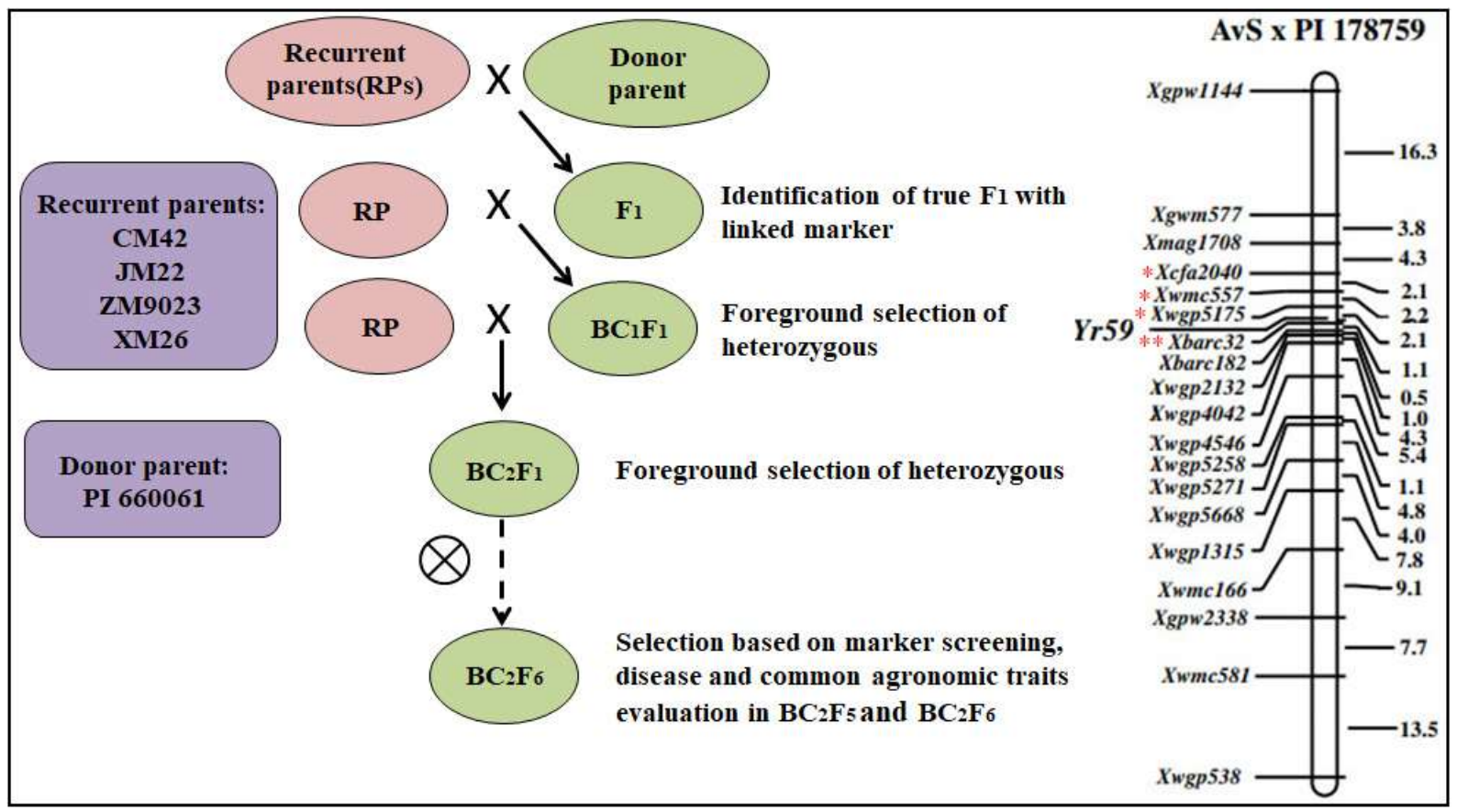

Figure 1. The scheme of introgressing stripe rust resistance gene $Y_{r} 59$ into four elite wheat cultivars through marker-assisted backcrossing (MABC). The Yr59 linkage map was adopted from Zhou et al. (2014). The marker with two asterisks ${ }^{* *}$ ) was used in genotyping $\mathrm{F}_{1}, \mathrm{BC}_{1} \mathrm{~F}_{1}$ and $\mathrm{BC}_{2} \mathrm{~F}_{1}$ plants, and the markers with one $\left(^{*}\right)$ and two asterisks $\left(^{* *}\right)$ were used to screen the $\mathrm{BC}_{2} \mathrm{~F}_{5}$ and $\mathrm{BC}_{2} \mathrm{~F}_{6}$ lines. 
Table 2. Numbers of progeny plants (for $\mathrm{F}_{1}, \mathrm{BC}_{1} \mathrm{~F}_{1}$ and $\mathrm{BC}_{2} \mathrm{~F}_{1}$ ) or lines $\left(\mathrm{BC}_{2} \mathrm{~F}_{5}\right.$ and $\mathrm{BC}_{2} \mathrm{~F}_{6}$ ) tested and positive for $Y r 59$-linked SSR markers in different generations derived from wheat crosses of four elite cultivars (CM42, JM22, ZM9023 and XM26) with Yr59 donor PI 660061). The $\mathrm{F}_{1}, \mathrm{BC}_{1} \mathrm{~F}_{1}$, $\mathrm{BC}_{2} \mathrm{~F}_{1}$ generations were screened with $\mathrm{Xbarc32}$, and $\mathrm{BC}_{2} \mathrm{~F}_{5}$ and $\mathrm{BC}_{2} \mathrm{~F}_{6}$ were screened with $\mathrm{Xbarc32}$, Xwgp5175, Xwmc557 and Xcfa2040.

\begin{tabular}{|c|c|c|c|c|c|c|c|c|c|c|}
\hline \multirow{3}{*}{ Generations } & \multicolumn{10}{|c|}{ Number of Plants/Lines } \\
\hline & \multicolumn{2}{|c|}{ CM42/PI660061 } & \multicolumn{2}{|c|}{ JM22/PI660061 } & \multicolumn{2}{|c|}{ ZM9023/PI660061 } & \multicolumn{2}{|c|}{ XM26/PI660061 } & \multicolumn{2}{|c|}{ Total } \\
\hline & Tested & Positive & Tested & Positive & Tested & Positive & Tested & Positive & Tested & Positive \\
\hline $\mathrm{F}_{1}$ & 10 & 8 & 13 & 9 & 9 & 7 & 11 & 9 & 43 & 33 \\
\hline $\mathrm{BC}_{1} \mathrm{~F}_{1}$ & 13 & 6 & 15 & 7 & 10 & 4 & 12 & 6 & 50 & 23 \\
\hline $\mathrm{BC}_{2} \mathrm{~F}_{1}$ & 24 & 12 & 31 & 16 & 20 & 10 & 23 & 11 & 98 & 49 \\
\hline $\mathrm{BC}_{2} \mathrm{~F}_{5}$ & 28 & 28 & 43 & 39 & 19 & 16 & 33 & 26 & 123 & 109 \\
\hline $\mathrm{BC}_{2} \mathrm{~F}_{6}$ & 28 & 28 & 43 & 39 & 19 & 16 & 33 & 26 & 123 & 109 \\
\hline
\end{tabular}

CM42: Chuanmai 42; JM22: Jimai 22; ZM9023: Zhengmai 9023; and XM26: Xinmai 26.

\subsection{Evaluation of Disease Resistance}

In the crop seasons of 2019-2020 and 2020-2021 in Mianyang and 2020-2021 in Yangling, the male parent, PI 660061, was highly resistant with IT 1-3, DS $<20 \%$, and the recurrent parents CM42, JM22, ZM9023 and XM26 had IT 7-8, DS 60-80\% with abundant uredinia (Figure 2). The majority of the 123 backcross progenies had IT values of $2-3$ and DS values of $5-20 \%$ in the three environments (Figure 3). A total of 26 lines of $\mathrm{BC}_{2} \mathrm{~F}_{5}$ and $\mathrm{BC}_{2} \mathrm{~F}_{6}$ generations from $\mathrm{CM} 42$ / / / CM42//CM42/PI660061 were resistant, while only 2 lines were intermediately resistant (Table 3$)$. The number of resistant, intermediate and susceptible lines of JM22/ / /JM22/ /JM22/PI660061 were 39, 2 and 2, respectively. The cross XM26/ / / XM26/ / XM26/PI660061 produced 28 resistant lines, 4 intermediate lines and 1 susceptible line. The cross of ZM9023 / / ZM9023/ / ZM9023/PI660061 resulted in 17 resistant lines, 1 intermediate line and 1 susceptible line. Lines carrying $Y r 59$ had low IT $(<4)$ and DS $(<40)$ (Figure 4$)$. The $t$-test results also prove the point (Figure 5). All these results indicated that introgression $Y r 59$ into elite wheat cultivars could effectively improve resistance to stripe rust. Additionally, lines possessing both Yr59 and Yr26 or both Yr59 and $Y$ rJ22 had mostly had higher levels of stripe rust resistance than those containing only Yr59 (Table 4).

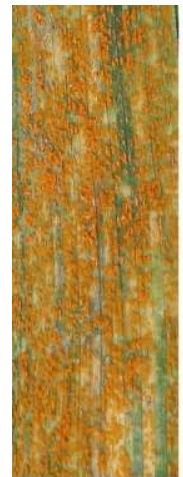

M169

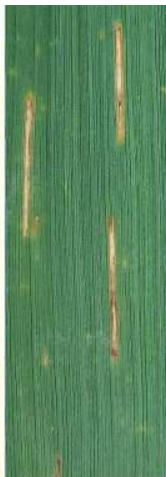

PI 660061

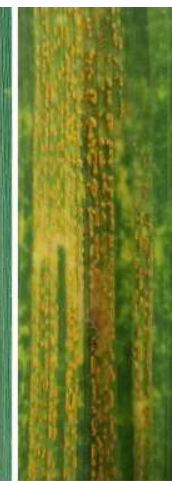

$\mathrm{CM} 42$

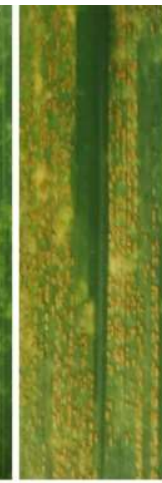

JM22

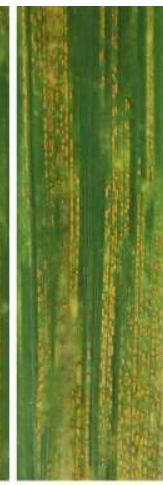

ZM9023

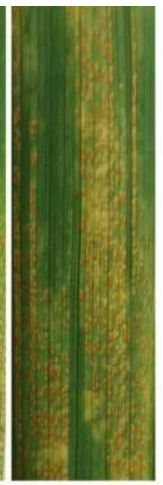

XM26

(A)

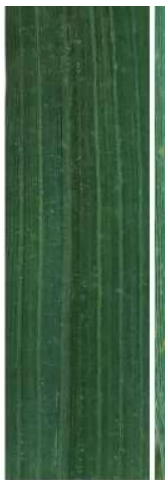

$\mathrm{IT}=0$

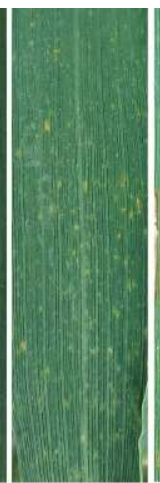

$\mathrm{IT}=1$

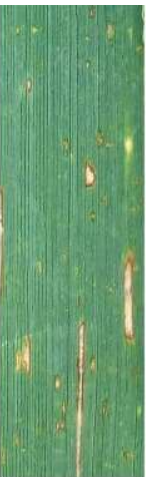

$\mathrm{IT}=2$

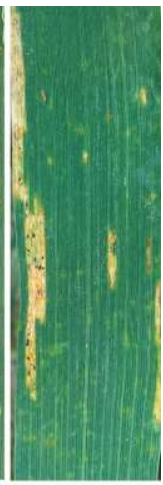

$\mathrm{IT}=3$

(B)

Figure 2. Adult-plant stripe rust reactions on leaves of five parents and susceptible control M169 (A); phenotype of sixteen final selected posterities, $\mathrm{IT}=0$ (including $\mathrm{BC}_{2} \mathrm{~F}_{6}-73$ ), IT $=1$ (including $\mathrm{BC}_{2} \mathrm{~F}_{6}-21, \mathrm{BC}_{2} \mathrm{~F}_{6}-86, \mathrm{BC}_{2} \mathrm{~F}_{6}-97$ ), $\mathrm{IT}=2$ (including $\mathrm{BC}_{2} \mathrm{~F}_{6}-28, \mathrm{BC}_{2} \mathrm{~F}_{6}-48, \mathrm{BC}_{2} \mathrm{~F}_{6}-59, \mathrm{BC}_{2} \mathrm{~F}_{6}-65, \mathrm{BC}_{2} \mathrm{~F}_{6}-84$, $\mathrm{BC}_{2} \mathrm{~F}_{6}-85, \mathrm{BC}_{2} \mathrm{~F}_{6}-106, \mathrm{BC}_{2} \mathrm{~F}_{6}-107$ ), $\mathrm{IT}=3$ (including $\mathrm{BC}_{2} \mathrm{~F}_{6}-33, \mathrm{BC}_{2} \mathrm{~F}_{6}-40, \mathrm{BC}_{2} \mathrm{~F}_{6}-61, \mathrm{BC}_{2} \mathrm{~F}_{6}-96$ ) (B). 

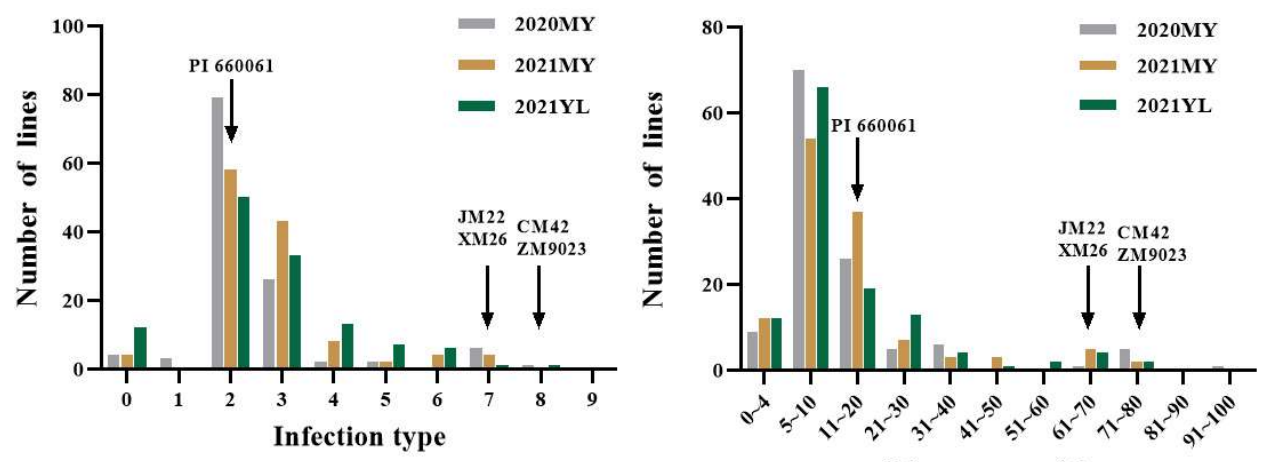

Disease severities

Figure 3. Distributions of mean infection type (IT) and disease severity (DS) for 123 Introgression Lines (ILs) from the four crosses of CM42/ / CM42 / /CM42/PI660061, JM22/ / JM22/ /JM22/PI660061, ZM9023 / / ZM9023 / ZM9023/PI660061 and XM26/ / XM26/ /XM26/PI660061 at Yangling (YL) and Mianyang (MY) in 2019-2021. Arrows indicate the scores of the parental lines.

Table 3. Numbers of introgression lines of the four crosses classified in the resistant, intermediate and susceptible categories in the light of mean infection types (IT) over two years and three locations.

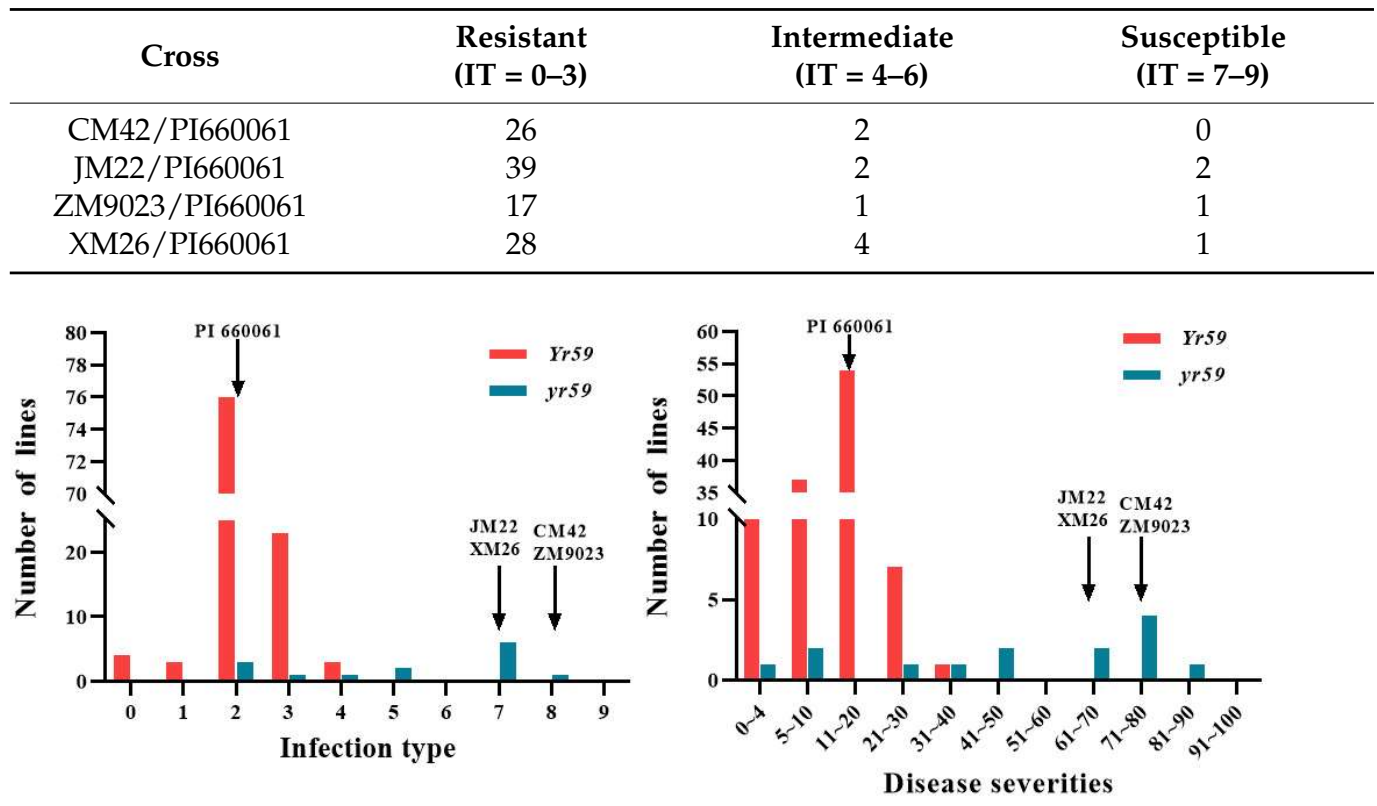

Figure 4. Comparison of 123 ILs for mean final infection type and disease severity about the presence (Yr59) and absence (yr59) of the stripe rust resistance gene Yr59.

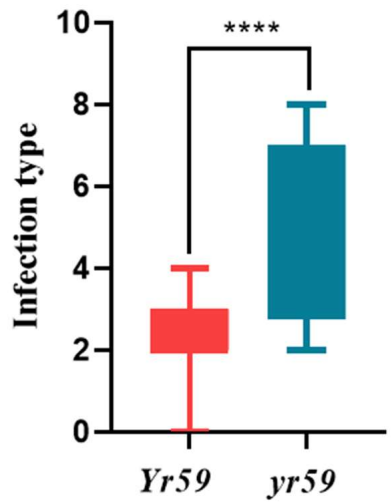

Figure 5. Infection type scores of $Y r 59$ and yr59 lines from four populations. "Yr59" represents the presence of Yr59; " $y r 59$ " represents the absence of Yr59. P-value was generated by the $t$-test. $* * * *$ Significantly different at $p<0.05$ (n.s., no significance at $p>0.05$ ). 
Table 4. $Y r$ genes detected by molecular markers, infection types (IT) and disease severity (DS) of stripe rust and agronomic traits of plant height (PH), number of spikes (NS), grain number per spike (GNS), spike length (SL) and thousand-grain weight (TWG) of parents and progeny lines.

\begin{tabular}{|c|c|c|c|c|c|c|c|c|c|}
\hline \multirow[b]{2}{*}{ Line } & \multirow[b]{2}{*}{ Parent/Crosses } & \multicolumn{3}{|c|}{ Stripe Rust } & \multicolumn{5}{|c|}{ Agronomic Trait } \\
\hline & & Gene & IT & DS (\%) & PH (cm) & NS & GNS & SL (cm) & $\begin{array}{c}\text { TGW } \\
\text { (g) }\end{array}$ \\
\hline M169 & Susc. check & No & 9 & 100 & 116.0 & 5.0 & 39.0 & 10.3 & 38.1 \\
\hline PI 660061 & Res. donor & Yr59 & 2 & 20 & 125.1 & 8.0 & 45.0 & 8.7 & 39.5 \\
\hline CM42 & Elite parent & $Y r 26$ & 6 & 75 & 91.3 & 5.0 & 40.0 & 7.1 & 42.8 \\
\hline JM22 & Elite parent & YrJ22 & 5 & 60 & 82.6 & 4.0 & 44.0 & 9.3 & 43.5 \\
\hline ZM9023 & Elite parent & Unknown & 5 & 70 & 86.4 & 4.0 & 41.0 & 7.1 & 42.4 \\
\hline XM26 & Elite parent & Unknown & 5 & 60 & 83.2 & 5.0 & 39.0 & 8.1 & 48.2 \\
\hline $\mathrm{BC}_{2} \mathrm{~F}_{6}-7$ & JM22/PI660061 & $Y r 59+Y r J 22$ & 1 & 5 & 92.1 & 13.0 & 49.0 & 9.6 & 42.2 \\
\hline $\mathrm{BC}_{2} \mathrm{~F}_{6}-8$ & JM22/PI660061 & $Y r 59+Y r J 22$ & 2 & 8 & 89.3 & 7.0 & 49.0 & 9.8 & 41.8 \\
\hline $\mathrm{BC}_{2} \mathrm{~F}_{6}-21$ * & JM22/PI660061 & Yr59 & 1 & 7 & 93.5 & 9.0 & 55.0 & 9.0 & 46.6 \\
\hline $\mathrm{BC}_{2} \mathrm{~F}_{6}-27$ & JM22/PI660061 & Yr59 & 3 & 20 & 95.3 & 10.0 & 47.0 & 11.1 & 42.3 \\
\hline $\mathrm{BC}_{2} \mathrm{~F}_{6}-28$ * & JM22/PI660061 & Yr59 & 2 & 13 & 97.2 & 7.0 & 58.0 & 9.4 & 43.1 \\
\hline $\mathrm{BC}_{2} \mathrm{~F}_{6}-33$ * & JM22/PI660061 & $Y r 59+Y r J 22$ & 3 & 5 & 88.1 & 9.0 & 59.0 & 10.0 & 44.7 \\
\hline $\mathrm{BC}_{2} \mathrm{~F}_{6}-40$ * & JM22/PI660061 & $Y r 59+Y r J 22$ & 3 & 15 & 94.8 & 7.0 & 56.0 & 10.2 & 42.0 \\
\hline $\mathrm{BC}_{2} \mathrm{~F}_{6}-48$ * & CM42/PI660061 & $Y r 59+Y r 26$ & 2 & 15 & 95.6 & 8.0 & 56.0 & 10.5 & 43.6 \\
\hline $\mathrm{BC}_{2} \mathrm{~F}_{6}-59$ * & CM42/PI660061 & Yr59 & 2 & 8 & 97.8 & 7.0 & 56.0 & 10.1 & 47.5 \\
\hline $\mathrm{BC}_{2} \mathrm{~F}_{6}-61$ * & CM42/PI660061 & $Y r 59+Y r 26$ & 3 & 18 & 99.7 & 7.0 & 61.0 & 10.0 & 46.0 \\
\hline $\mathrm{BC}_{2} \mathrm{~F}_{6}-65$ * & CM42/PI660061 & Yr59 & 2 & 13 & 99.3 & 5.0 & 56.0 & 9.0 & 52.7 \\
\hline $\mathrm{BC}_{2} \mathrm{~F}_{6}-69$ & CM42/PI660061 & $Y r 59+Y r 26$ & 3 & 17 & 90.6 & 7.0 & 51.0 & 9.4 & 43.8 \\
\hline $\mathrm{BC}_{2} \mathrm{~F}_{6}-72$ & ZM9023/PI660061 & Yr59 & 2 & 8 & 85.1 & 6.0 & 43.0 & 8.9 & 44.2 \\
\hline $\mathrm{BC}_{2} \mathrm{~F}_{6}-73$ * & ZM9023/PI660061 & Yr59 & 0 & 0 & 88.7 & 6.0 & 46.0 & 8.3 & 57.6 \\
\hline $\mathrm{BC}_{2} \mathrm{~F}_{6}-78$ & ZM9023/PI660061 & Yr59 & 2 & 13 & 97.0 & 8.0 & 46.0 & 8.4 & 40.3 \\
\hline $\mathrm{BC}_{2} \mathrm{~F}_{6}-84$ * & ZM9023/PI660061 & Yr59 & 2 & 4 & 97.7 & 8.0 & 45.0 & 10.2 & 58.1 \\
\hline $\mathrm{BC}_{2} \mathrm{~F}_{6}-85$ * & ZM9023/PI660061 & Yr59 & 2 & 17 & 86.1 & 7.0 & 45.0 & 9.3 & 50.0 \\
\hline $\mathrm{BC}_{2} \mathrm{~F}_{6}-86^{*}$ & ZM9023/PI660061 & Yr59 & 1 & 5 & 96.2 & 7.0 & 42.0 & 10.3 & 57.8 \\
\hline $\mathrm{BC}_{2} \mathrm{~F}_{6}-96^{*}$ & XM26/PI660061 & Yr59 & 3 & 12 & 82.8 & 7.0 & 51.0 & 9.2 & 49.4 \\
\hline $\mathrm{BC}_{2} \mathrm{~F}_{6}-97$ * & XM26/PI660061 & Yr59 & 2 & 5 & 99.4 & 7.0 & 43.0 & 10.2 & 53.7 \\
\hline $\mathrm{BC}_{2} \mathrm{~F}_{6}-98$ & XM26/PI660061 & Yr59 & 2 & 4 & 87.1 & 5.0 & 43.0 & 8.7 & 54.8 \\
\hline $\mathrm{BC}_{2} \mathrm{~F}_{6}-102$ & XM26/PI660061 & Yr59 & 3 & 15 & 96.8 & 6.0 & 56.0 & 8.5 & 44.1 \\
\hline $\mathrm{BC}_{2} \mathrm{~F}_{6}-106^{*}$ & XM26/PI660061 & Yr59 & 3 & 20 & 96.5 & 6.0 & 61.0 & 10.5 & 44.1 \\
\hline $\mathrm{BC}_{2} \mathrm{~F}_{6}-107$ * & XM26/PI660061 & Yr59 & 3 & 13 & 88.6 & 7.0 & 60.0 & 9.3 & 43.0 \\
\hline $\mathrm{BC}_{2} \mathrm{~F}_{6}-116$ & XM26/PI660061 & Yr59 & 3 & 12 & 94.8 & 6.0 & 58.0 & 9.2 & 42.6 \\
\hline
\end{tabular}

* The lines were eventually selected to be released as new germplasm resource.

\subsection{Evaluation of Agronomic Traits}

Various agronomic traits (including PH, NS, GNS, SL and TGW) of the parents and $123 \mathrm{BC}_{2} \mathrm{~F}_{5}$ or $\mathrm{BC}_{2} \mathrm{~F}_{6}$ lines were assessed during the 2019-2020 and 2020-2021 growing season in Mianyang and Yangling. The mean PH of five parents: PI 660061, CM42, JM22, ZM9023 and XM26 were 125.1, 91.3, 82.6, 86.4, 83.2, respectively, whereas the selected progeny lines had $80.0-110.0 \mathrm{~cm}$ (Figure 6), which were desirable for growing in the regions of the elite cultivar parents from. The mean NS values of the five parents were 8.0, 5.0, 4.0, 4.0 and 5.0, respectively, and the NS values in the selected progeny lines exceeded that of their female parents, mostly ranged from 6.0 to 10.0. The mean SL value of each parent was $8.7 \mathrm{~cm}$ of PI660061, 7.1 cm of CM42, $9.3 \mathrm{~cm}$ of JM22, $7.1 \mathrm{~cm}$ of ZM9023 and $8.1 \mathrm{~cm}$ of XM26. Their selected plants had SL values mostly between 8.0 and $11.0 \mathrm{~cm}$. The mean GNS values of the five parents were 45.0, 40.0, 44.0, 41.0 and 39.0, while the selected progeny lines had 46.0-60.0 grains per spike, significantly higher than their donor parent and recurrent parents. The mean TWG values of the five parents were 39.5, 42.8, 43.5, 42.4 and $48.2 \mathrm{~g}$, respectively while the mean TWG values of their selected progeny lines majorly ranged from 40.0 to $50.0 \mathrm{~g}$. The TWG values of the selected progeny lines from cross JM22///JM22//JM22/PI660061 ranged mainly from 30.0 to $50.0 \mathrm{~g}$ (Figure 6). These 
important agronomic traits had been improved to varying degrees for reaching the goal of releasing new cultivars in the various wheat growing regions.

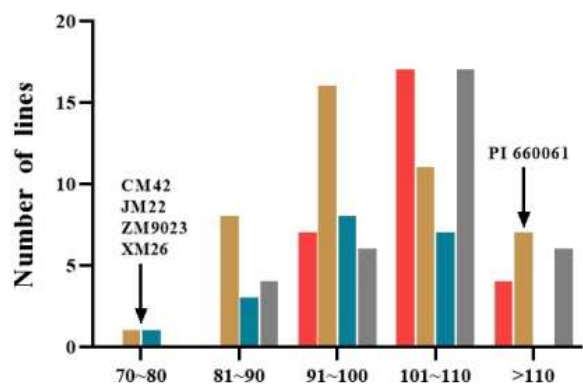

PH(cm)

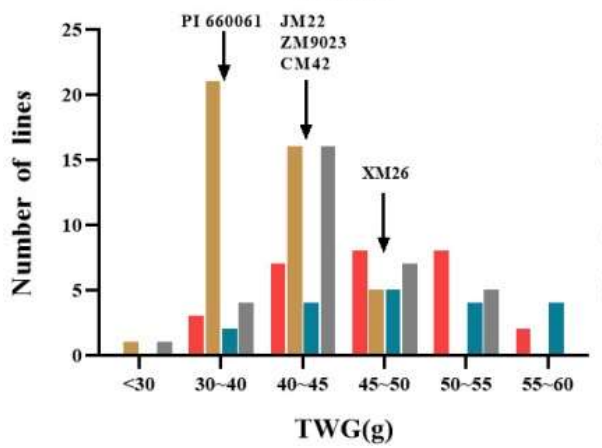

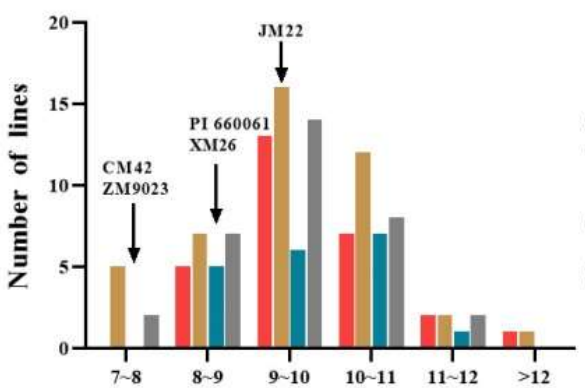

SL(cm)

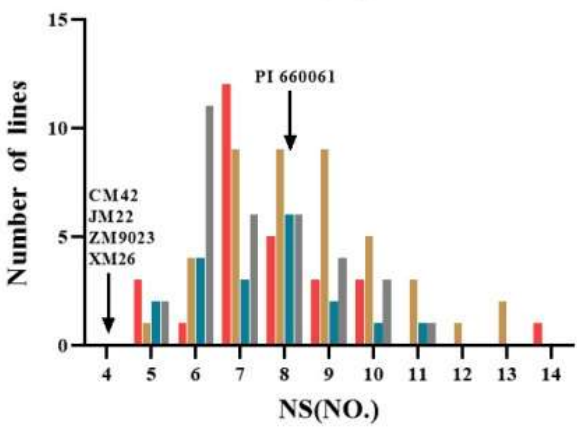

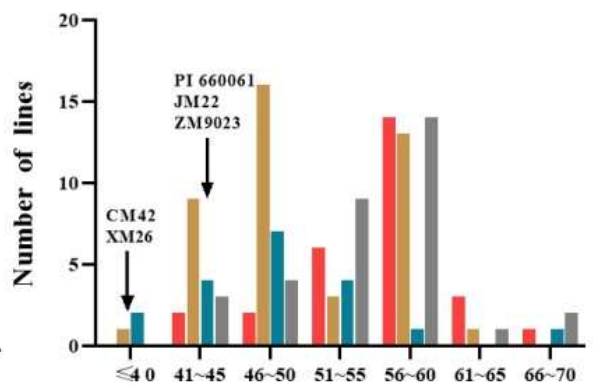

GNS(NO.)

Figure 6. Frequency distributions of agronomic traits for the 123 ILs from the four populations. plant height (PH); spike length (SL); grain number per spike (GNS); thousand-grain weight (TGW); number of spikes (NS).

As elite wheat cultivars with excellent agronomic traits, the four recurrent parents were used as the reference standards for selection of the final lines with Yr59. The 25 selected lines had PH between 80.0 and $100.0 \mathrm{~cm}$ for lodging resistance and easy harvesting; NS and GNS equal to or more than 5.0 and 40.0, respectively; SL over $8.0 \mathrm{~cm}$; and TGW of $40.0 \mathrm{~g}$ or greater (Table 4). Of the 25 lines, 5 were from the cross of CM42/ / CM42/ /CM42/PI660061, 7 from JM22 / / /JM22 / /JM22/PI660061, 6 from ZM9023 / / /ZM9023 / /ZM9023/ZM9023 and 7 from XM26///XM26//XM26/PI660061. These lines had IT 0 to 3 and DS less than $20 \%$. Further narrowed selection by screening suitable tiller numbers to prevent lodging and maximize wheat yield. Eventually, 16 lines were selected from the 25 lines, 4 from each of the 4 crosses. These lines were $\mathrm{BC}_{2} \mathrm{~F}_{6}-21, \mathrm{BC}_{2} \mathrm{~F}_{6}-28, \mathrm{BC}_{2} \mathrm{~F}_{6}-33$ and $\mathrm{BC}_{2} \mathrm{~F}_{6}-40$ (from JM22///JM22//JM22/PI660061); $\mathrm{BC}_{2} \mathrm{~F}_{6}-48, \mathrm{BC}_{2} \mathrm{~F}_{6}-59, \mathrm{BC}_{2} \mathrm{~F}_{6}-61$ and $\mathrm{BC}_{2} \mathrm{~F}_{6}-65$ (from CM42/ / /CM42/ /CM42/PI660061); $\mathrm{BC}_{2} \mathrm{~F}_{6}-73, \mathrm{BC}_{2} \mathrm{~F}_{6}-84, \mathrm{BC}_{2} \mathrm{~F}_{6}-85$ and $\mathrm{BC}_{2} \mathrm{~F}_{6}-86$ (from ZM9023/ / / ZM9023/ / ZM9023/PI660061); $\mathrm{BC}_{2} \mathrm{~F}_{6}-96, \mathrm{BC}_{2} \mathrm{~F}_{6}-97, \mathrm{BC}_{2} \mathrm{~F}_{6}-106$ and $\mathrm{BC}_{2} \mathrm{~F}_{6}-107$ (from XM26// / XM26/ / XM26/PI660061). Among the 16 final lines, $\mathrm{BC}_{2} \mathrm{~F}_{6}-48$ and $\mathrm{BC}_{2} \mathrm{~F}_{6}{ }^{-}$ 61 had $Y$ r26, and $\mathrm{BC}_{2} \mathrm{~F}_{6}-33$ and $\mathrm{BC}_{2} \mathrm{~F}_{6}-40$ had $Y_{r J 22}$ for race-specific ASR, in addition to Yr59 for non-race-specific HTAP resistance. The remaining 12 lines had Yr59. The specific results are shown in Table 4 .

In summary, we successfully introduced the HTAP stripe rust resistance gene $Y r 59$ into four elite wheat cultivars from different wheat growing regions in China. Through MAS, 109 families with resistance gene $Y r 59$ were selected from 123 lines, and 16 lines were finally selected based on their desirable agronomic traits. These lines showed high resistance to stripe rust (IT $\leq 3$; DS $\leq 20 \%)$; moderate plant height $(80-100 \mathrm{~cm})$; and yield-related traits including NS (5-9), SL (8.38-10.59) and GNS (42-61), and TGW were similar or superior to their elite parents, providing more options for wheat breeding. 


\section{Discussion}

Stripe rust is prevalent in many wheat areas in China and has caused serious damage. One of the main reasons for the frequent epidemics is the widely grown single wheat cultivars with one or few race-specific resistance genes, which creates directional selection pressure on the pathogen to produce new predominant races, circumventing the resistance genes [64]. As a result, the wheat cultivars become susceptible. With the development of MAS technology, wheat cultivars containing different resistance genes have been developed. For example, pyramiding lines (consisting of 3-8 Yr genes) were constructed by marker assistant selection for better stripe rust resistance [65]. Multiple genes/QTL, such as $Y r 70 / L r 76+L r 37 / Y r 17 / S r 38, G p c-B 1 / Y r 36+Q P h s . c c s u-3 A .1+Q G w . c c s u-1 A .3+L r 24 / S r 24+$ Glu-A1-1/Glu-A1-2, were successfully pyramided into wheat cultivars to improve resistance to stripe rust and other rusts as well as grain quality [66]. Wheat cultivar Guinong 19 was developed from the cross of Zhongyan 96-3 × Guinong 21 through MAS for powdery mildew resistance gene $P m 21$ [67].

Race CYR34 of Pst, which is virulent to resistance genes Yr26 $(=Y r 24)$ and $Y r 10$, has become predominant in recent years [68], resulting in many wheat cultivars with $Y r 26$ becoming susceptible, such as Guinong 22 and Chuanmai 42, both with Yr26, as well as Zhengmai 9023 with unknown stripe rust resistance genes. Through our disease resistance assessments in the field over the years, PI 660061 has still maintained resistance to CYR34 and many other races, as its HTAP resistance controlled by $Y r 59$ is non-race-specific [36]. As the gene was recently identified from an Iraq landrace (PI 178759), its use in breeding programs has just started. As PI 660061 was developed as an improved germplasm from PI 178759 for $Y r 59$ [56], PI 660061 was selected as the donor parent to cross with four high yield wheat cultivars, CM42, JM22, ZM9023 and XM26 from different wheat growing regions of China. Four markers, Xbarc32, Xwgp5175, Xwmc557 and Xcfa2040, linked with Yr59 were used to detect the gene in the progeny populations. Given three of the four are SSR markers, recombination between markers and gene may occur, which might affect the results of marker detection. Thus, we combined marker selection with field stripe rust screening to ensure as much as possible that $Y r 59$ was successfully introduced into the backgrounds of the four recipient parents. Finally, through the screening of agronomic characters, 16 lines with $Y r 59$ in combinations with multiple desirable agronomic traits were selected.

According to the reports, CM42 and JM22 have race-specific ASR genes Yr26 and YrJ22, respectively [48-50]. In our results, almost all lines carrying Yr59 showed high level of resistance with IT scores lower than 3 and DS less than 20\%. Some lines having Yr59 together with $Y r 26$ or $Y r J 22$ exhibited stronger resistance than lines containing only $Y r 59$ from crosses CM42///CM42//CM42/PI660061 and JM22/PI660061//JM22///JM22. This may because of the combination of effects from both genes. Surprisedly, the enhancing effect may also happen in the crosses of ZM9023/PI660061//ZM9023///ZM9023 and XM26// /XM26//XM26/PI660061. There were several lines without Yr59 in ZM9023/// ZM9023//ZM9023/PI660061 and XM26///XM26//XM26/PI660061 that displayed some levels of resistance. As ZM9023 and XM26 were less susceptible than the susceptible check (Table 4), they should have unknown resistance genes. The combinations of the unknown resistance genes with $Y r 59$ should enhance resistance. A recent study reported that ZM9023 contains $Y r 29$ and $Y r 30$ for adult-plant resistance to stripe rust as well as Lr46/Sr59/Pm39 and Lr27/Sr2 for resistance to leaf rust/stem rust or powdery mildew linked to or pleiotropic with the stripe rust resistance genes, respectively [69].

Through our multi-year field tests, we showed that PI 660061 was easy lodging due to high plant height and excessive tillers. In the present study, PI 660061 was crossed with four superior cultivars, and this unfavorable trait was significantly improved. Yield is another important trait in wheat production, which was reflected partly by the number of grains per spike and 1000-grain weight. Pyramided Yr59 into the backgrounds of these four cultivars helped to improve the stripe rust resistance and maintained the similar or even improved the traits of grains per spike and number of spikes compared with their recurrent parents. In the backcross of JM22/ / JM22//JM22/PI660061, a half of the progeny lines 
had thousand-grain weight less than their recurrent parent, but this may be compensated by the improved spike grain number and number of spikes to a large extent.

Generally, MABC requires both foreground selection and background selection. In this study, we did not carry out marker detection and comprehensive evaluation selection in every generation. Instead, marker-assisted selection was carried out in the $\mathrm{F}_{1}, \mathrm{BC}_{1} \mathrm{~F}_{1}$ and $\mathrm{BC}_{2} \mathrm{~F}_{2}$ generations, and the selected $\mathrm{BC}_{2} \mathrm{~F}_{2}$ plants were subsequently advanced through selfing to the $\mathrm{BC}_{2} \mathrm{~F}_{4}$ generation for comprehensive evaluation and selection of agronomic traits and stripe rust resistance. To preserve all potential genotypes and reduce the loss of desirable heterozygous plants, bulk harvest was performed before the $\mathrm{BC}_{2} \mathrm{~F}_{4}$ generation [70]. Final selection was done based on phenotyping for the resistance and agronomic traits. Because Mianyang is a hot spot of stripe rust, it provides conditions for reliable identification of stripe rust resistance. Thus, we screened for stripe rust resistance in the $\mathrm{BC}_{2} \mathrm{~F}_{4}$ generation. Through preliminary screening of stripe rust resistance and agronomic traits of $\mathrm{BC}_{2} \mathrm{~F}_{4}$ in the field, we found that the proportion of lines with stripe rust resistance was significantly increased, saving the cost and labor for the next step of marker-assisted selection. This procedure reduces the working intensity and ensures the correctness of the selection. Nevertheless, the lines we selected in this study were stable. Marker detection for targeting stripe rust resistance genes and phenotype evaluation of stripe rust resistance and agronomic traits were performed in both the $\mathrm{BC}_{2} \mathrm{~F}_{5}$ (Mianyang) and $\mathrm{BC}_{2} \mathrm{~F}_{6}$ (Mianyang and Yangling) generations. The consistent results in multiple environments prove the reliability of the selection results.

\section{Conclusions}

The emergence and prevalence of new Pst races may have destructive impacts on wheat production, which requires timely excavation and utilization of new disease-resistance genes, even better genes for non-race-specific, adequate and durable resistance. In the current study, we successfully transferred $Y r 59$ for an adequate level of HTAP resistance, a type of stripe rust resistance that has been demonstrated to be non-race-specific and durable [31,71,72], into four Chinese elite wheat cultivars and selected 16 lines with strong stripe rust resistance and desirable agronomic traits through MABC. These pyramided lines provide genetic resources for breeding new wheat cultivars with durable resistance to stripe rust and may be released as new cultivars to certain wheat production regions after evaluation for yield, quality, adaptation and resistance to other major diseases and pests in various regions.

Author Contributions: M.Z. and X.Z. detected the gene, collected samples, analyzed the data and prepared the first draft of the manuscript. M.Z. and T.F. contributed to field investigation and samples collection. X.Z. and X.C. contributed to the crosses and revised the draft. X.L., J.F. and S.Y. contributed to the selection target lines and evaluated the populations. X.Z., X.C. and Z.K. conceived the project and generated the final version of the manuscript. All authors have read and agreed to the published version of the manuscript.

Funding: This work was financially supported by the Key Research and Development Program of International Science and Technology Innovation Cooperation of Science and Technology Department of Sichuan Province, China (No. 22GJHZ0288), and was partially funded by the National Natural Science Foundation of China (No. 32101707), PhD Foundation of Southwest University of Science and Technology (No. 18zx7159), Breakthrough in Wheat Breeding Material and Method Innovation and New Variety Breeding (Breeding Research Project, 2021YFYZ0002), Longshan Academic Talent Research Support Program of SWUST (No. 17LZX5) and PhD Foundation of Southwest University of Science and Technology (No. 16zx7162).

Institutional Review Board Statement: Not applicable.

Informed Consent Statement: Not applicable.

Data Availability Statement: The datasets analyzed during the current study are available from the corresponding author on reasonable request. 
Acknowledgments: The authors acknowledge the Crop Molecular Breeding Platform of Sichuan Province for providing necessary infrastructure and research facilities for carrying out this work and Biotechnology and Nuclear Technology Research Institute, Sichuan Academy of Agricultural Sciences, for assistance with this research.

Conflicts of Interest: The authors declare no conflict of interest.

\section{References}

1. Gupta, P.K.; Kumar, J.; Mir, R.R.; Kumar, A. Marker-Assisted Selection as a Component of Conventional Plant Breeding. Plant Breed. Rev. 2010, 33, 145-217. [CrossRef]

2. Wellings, C.R. Global status of stripe rust: A review of historical and current threats. Euphytica 2011, 179, 129-141. [CrossRef]

3. Chen, X. Pathogens which threaten food security: Puccinia striiformis, the wheat stripe rust pathogen. Food Secur. 2020, 12, 239-251. [CrossRef]

4. Zhou, X.; Fang, T.; Li, K.; Huang, K.; Ma, C.; Zhang, M.; Li, X.; Yang, S.; Ren, R.; Zhang, P. Yield losses associated with different levels of stripe rust resistance of commercial wheat cultivars in China. Phytopathology 2021. [CrossRef]

5. Collard, B.; Mackill, D.J. Marker-assisted selection: An approach for precision plant breeding in the twenty-first century. Philos. Trans. R. Soc. B Biol. Sci. 2007, 363, 557-572. [CrossRef] [PubMed]

6. $\quad$ Panigrahi, J.; Mishra, R.R.; Sahu, A.R.; Rath, S.C.; Kole, C.R. Marker-Assisted Breeding for Stress Resistance in Crop Plants. In Molecular Stress Physiology of Plants; Springer: Berlin/Heidelberg, Germany, 2013; pp. 387-426.

7. Toojinda, T.; Baird, E.; Booth, A.; Broers, L.; Hayes, P.; Powell, W.; Thomas, W.; Vivar, H.; Young, G. Introgression of quantitative trait loci (QTLs) determining stripe rust resistance in barley: An example of marker-assisted line development. Theor. Appl. Genet. 1998, 96, 123-131. [CrossRef]

8. Dubcovsky, J. Marker-Assisted Selection in Public Breeding Programs. Crop Sci. 2004, 44, 1895-1898. [CrossRef]

9. Merrick, L.F.; Burke, A.B.; Chen, X.M.; Carter, A.H. Breeding with major and minor genes: Ge-nomic selection for quantitative disease resistance. Front. Plant Sci. 2021, 12, 713667. [CrossRef]

10. Prasanna, B.M.; Pixley, K.; Warburton, M.L.; Xie, C.-X. Molecular marker-assisted breeding options for maize improvement in Asia. Mol. Breed. 2010, 26, 339-356. [CrossRef]

11. Varshney, R.K.; Pandey, M.; Janila, P.; Nigam, S.N.; Sudini, H.; Gowda, M.V.C.; Sriswathi, M.; Radhakrishnan, T.; Manohar, S.S.; Nagesh, P. Marker-assisted introgression of a QTL region to improve rust resistance in three elite and popular varieties of peanut (Arachis hypogaea L.). Theor. Appl. Genet. 2014, 127, 1771-1781. [CrossRef]

12. Leal-Bertioli, S.C.; Cavalcante, U.; Gouveia, E.G.; Taborda, C.B.; Shirasawa, K.; Guimarães, P.M.; Jackson, S.; Bertioli, D.J.; Moretzsohn, M.C. Identification of QTLs for Rust Resistance in the Peanut Wild Species Arachis magna and the Development of KASP Markers for Marker-Assisted Selection. G3 Genes I Genomes I Genet. 2015, 5, 1403-1413. [CrossRef] [PubMed]

13. Fujino, K.; Hirayama, Y.; Kaji, R. Marker-assisted selection in rice breeding programs in Hokkaido. Breed. Sci. 2019, 69, 383-392. [CrossRef]

14. Karunarathna, K.H.T.; Mewan, K.M.; Weerasena, O.V.D.S.J.; Perera, S.A.C.N.; Edirisinghe, E.N.U. A functional molecular marker for detecting blister blight disease resistance in tea (Camellia sinensis L.). Plant Cell Rep. 2021, 40, 351-359. [CrossRef] [PubMed]

15. He, D.; Zhang, J.; Zhang, X.; He, S.; Xie, D.; Liu, Y.; Li, C.; Wang, Z.; Liu, Y. Development of SSR markers in Paeonia based on De Novo transcriptomic assemblies. PLoS ONE 2020, 15, e227794. [CrossRef]

16. Vishwakarma, M.K.; Arun, B.; Mishra, V.K.; Yadav, P.S.; Kumar, H.; Joshi, A.K. Marker-assisted improvement of grain protein content and grain weight in Indian bread wheat. Euphytica 2016, 208, 313-321. [CrossRef]

17. Yaniv, E.; Raats, D.; Ronin, Y.; Korol, A.B.; Grama, A.; Bariana, H.; Dubcovsky, J.; Schulman, A.H.; Fahima, T. Evaluation of marker-assisted selection for the stripe rust resistance gene Yr15, introgressed from wild emmer wheat. Mol. Breed. $2015,35,43$. [CrossRef]

18. Mallick, N.; Vinod, G.P.C.S.J.B.; Sharma, J.B.; Tomar, R.; Sivasamy, M.; Prabhu, K. Marker-assisted backcross breeding to combine multiple rust resistance in wheat. Plant Breed. 2015, 134, 172-177. [CrossRef]

19. Randhawa, M.S.; Bains, N.S.; Sohu, V.S.; Chhuneja, P.; Trethowan, R.M.; Bariana, H.S.; Bansal, U. Marker Assisted Transfer of Stripe Rust and Stem Rust Resistance Genes into Four Wheat Cultivars. Agronomy 2019, 9, 497. [CrossRef]

20. Ragoussis, J. Genotyping technologies for all. Drug Discov. Today Technol. 2006, 3, 115-122. [CrossRef] [PubMed]

21. Kumpatla, S.P.; Buyyarapu, R.; Mammadov, J.; Abdurakhmonov, I. Genomics-Assisted Plant Breeding in the 21st Century: Technological Advances and Progress. In Plant Breeding; InTech: London, UK, 2012; pp. 131-183.

22. Rafalski, A. Applications of single nucleotide polymorphisms in crop genetics. Curr. Opin. Plant Biol. 2002, 5, 94-100. [CrossRef]

23. Hyten, D.L.; Cannon, S.B.; Song, Q.; Weeks, N.; Fickus, E.W.; Shoemaker, R.C.; Specht, J.E.; Farmer, A.D.; May, G.D.; Cregan, P.B. High-throughput SNP discovery through deep resequencing of a reduced representation library to anchor and orient scaffolds in the soybean whole genome sequence. BMC Genom. 2010, 11, 38. [CrossRef] [PubMed]

24. Thomson, M.J. High-Throughput SNP Genotyping to Accelerate Crop Improvement. Plant Breed. Biotechnol. $2014,2,195-212$. [CrossRef] 
25. Mu, J.; Huang, S.; Liu, S.; Zeng, Q.; Dai, M.; Wang, Q.; Wu, J.; Yu, S.; Kang, Z.; Han, D. Genetic architecture of wheat stripe rust resistance revealed by combining QTL mapping using SNP-based genetic maps and bulked segregant analysis. Theor. Appl. Genet. 2018, 132, 443-455. [CrossRef] [PubMed]

26. Neelam, K.; Brown-Guedira, G.; Huang, L. Development and validation of a breeder-friendly KASPar marker for wheat leaf rust resistance locus Lr21. Mol. Breed. 2012, 31, 233-237. [CrossRef]

27. Qie, Y.; Liu, Y.; Wang, M.; Li, X.; See, D.R.; An, D.; Chen, X. Development, Validation, and Re-selection of Wheat Lines with Pyramided Genes Yr64 and Yr15 Linked on the Short Arm of Chromosome 1B for Resistance to Stripe Rust. Plant Dis. 2019, 103, 51-58. [CrossRef]

28. Kaur, B.; Mavi, G.S.; Gill, M.S.; Saini, D.K. Utilization of KASP technology for wheat improvement. Cereal Res. Commun. 2020, 48, 409-421. [CrossRef]

29. Chen, X. Epidemiology and control of stripe rust [Puccinia striiformis f. sp. tritici] on wheat. Can. J. Plant Pathol. 2005, 27, 314-337. [CrossRef]

30. Rosewarne, G.M.; Herrera-Foessel, S.A.; Singh, R.P.; Huerta-Espino, J.; Lan, C.X.; He, Z.H. Quantitative trait loci of stripe rust resistance in wheat. Theor. Appl. Genet. 2013, 126, 2427-2449. [CrossRef]

31. Chen, X. Review Article: High-Temperature Adult-Plant Resistance, Key for Sustainable Control of Stripe Rust. Am. J. Plant Sci. 2013, 04, 608-627. [CrossRef]

32. Chen, X.; Penman, L.; Wan, A.; Cheng, P. Virulence races of Puccinia striiformis f. sp. triticiin 2006 and 2007 and development of wheat stripe rust and distributions, dynamics, and evolutionary relationships of races from 2000 to 2007 in the United States. Can. J. Plant Pathol. 2010, 32, 315-333. [CrossRef]

33. Wan, A.; Chen, X. Virulence Characterization of Puccinia striiformis f. sp. tritici Using a New Set of Yr Single-Gene Line Differentials in the United States in 2010. Plant Dis. 2014, 98, 1534-1542. [CrossRef]

34. Cheng, P.; Chen, X.M. Molecular mapping of a gene for stripe rust resistance in spring wheat cultivar IDO377s. Theor. Appl. Genet. 2010, 121, 195-204. [CrossRef]

35. Fu, D.; Uauy, C.; Distelfeld, A.; Blechl, A.; Epstein, L.; Chen, X.; Sela, H.; Fahima, T.; Dubcovsky, J. A Kinase-START Gene Confers Temperature-Dependent Resistance to Wheat Stripe Rust. Sci. 2009, 323, 1357-1360. [CrossRef] [PubMed]

36. Zhou, X.L.; Wang, M.N.; Chen, X.M.; Lu, Y.; Kang, Z.S.; Jing, J.X. Identification of Yr59 conferring high-temperature adult-plant resistance to stripe rust in wheat germplasm PI 178759. Theor. Appl. Genet. 2014, 127, 935-945. [CrossRef] [PubMed]

37. Wang, M.; Chen, X. Stripe Rust Resistance. In Stripe Rust; Springer: Berlin/Heidelberg, Germany, $2017 ;$ pp. 353-558.

38. Li, J.; Dundas, I.; Dong, C.; Li, G.; Trethowan, R.; Yang, Z.; Hoxha, S.; Zhang, P. Identification and characterization of a new stripe rust resistance gene Yr83 on rye chromosome 6R in wheat. Theor. Appl. Genet. 2020, 133, 1095-1107. [CrossRef] [PubMed]

39. Gupta, P.K.; Langridge, P.; Mir, R.R. Marker-assisted wheat breeding: Present status and future possibilities. Mol. Breed. 2010, 26, 145-161. [CrossRef]

40. Kaur, S.; Kaur, J.; Mavi, G.S.; Dhillon, G.S.; Sharma, A.; Singh, R.; Devi, U.; Chhuneja, P. Pyramiding of High Grain Weight With Stripe Rust and Leaf Rust Resistance in Elite Indian Wheat Cultivar Using a Combination of Marker Assisted and Phenotypic Selection. Front. Genet. 2020, 11, 593426. [CrossRef] [PubMed]

41. Zheng, W.; Li, S.; Liu, Z.; Zhou, Q.; Feng, Y.; Chai, S. Molecular marker assisted gene stacking for disease resistance and quality genes in the dwarf mutant of an elite common wheat cultivar Xiaoyan22. BMC Genet. 2020, 21, 45. [CrossRef]

42. Yang, Q.; Fang, T.; Li, X.; Ma, C.; Yang, S.; Kang, Z.; Zhou, X. Improving stripe rust resistance and agronomic performance in three elite wheat cultivars using a combination of phenotypic selection and marker detection of Yr48. Crop Prot. 2021, 148, 105752. [CrossRef]

43. Hu, T.; Zhong, X.; Yang, Q.; Zhou, X.; Li, X.; Yang, S.; Hou, L.; Yao, Q.; Guo, Q.; Kang, Z. Introgression of Two Quantitative Trait Loci for Stripe Rust Resistance into Three Chinese Wheat Cultivars. Agronomy 2020, 10, 483. [CrossRef]

44. Xu, W.; Hu, L.; Wang, G.; Zhang, L.; Dong, H.; Li, Y.; Zhang, J.; Zan, X.; Qi, X.; Li, C. Breeding strategies of high quality and wide regional adaptability wheat variety Zhengmai 9023 and relevant thoughts on wheat high yield breeding. J. Henan Agric. Sci. 2009, 9, 14-18.

45. Tang, Y.-L.; Li, J.; Wu, Y.-Q.; Wei, H.-T.; Li, C.-S.; Yang, W.-Y.; Chen, F. Identification of QTLs for Yield-Related Traits in the ecombinant Inbred Line Population Derived from the Cross Between a Synthetic Hexaploid Wheat-Derived Variety Chuanmai 42 and a Chinese Elite Variety Chuannong 16. Agric. Sci. China 2011, 10, 1665-1680. [CrossRef]

46. Li, H.; Song, J.; Liu, A.; Guo, D.; Wang, X.; Lin, D.; Zhao, Z.; Liu, J. Effect of sowing time and planting density on yield and components of 'Jimai22' with super-high yield. Chin. Agric. Sci. Bull. 2011, 27, 243-248.

47. Liu, X.; Li, M.; Wang, S.; Guo, C. Quality and utilization of new wheat variety Xinmai 26. J. Anhui Agric. Sci. 2018, 46, 31-33. [CrossRef]

48. Li, G.Q.; Li, Z.F.; Yang, W.Y.; Zhang, Y.; He, Z.H.; Xu, S.C.; Singh, R.P.; Qu, Y.Y.; Xia, X.C. Molecular mapping of stripe rust resistance gene YrCH42 in Chinese wheat cultivar Chuanmai 42 and its allelism with Yr24 and Yr26. Theor. Appl. Genet. 2006, 112, 1434-1440. [CrossRef]

49. Wang, C.; Zhang, Y.; Han, D.; Kang, Z.; Li, G.; Cao, A.; Chen, P. SSR and STS markers for wheat stripe rust resistance gene Yr26. Euphytica 2007, 159, 359-366. [CrossRef]

50. Chen, C.; He, Z.; Lu, J.; Li, J.; Ren, Y.; Ma, C.; Xia, X. Molecular mapping of stripe rust resistance gene YrJ22 in Chinese wheat cultivar Jimai 22. Mol. Breed. 2016, 36, 118. [CrossRef] 
51. Yin, G.-H.; Li, G.-Y.; He, Z.-H.; Liu, J.-J.; Wang, H.; Xia, X.-C. Molecular Mapping of Powdery Mildew Resistance Gene in Wheat Cultivar Jimai 22. Acta Agron. Sin. 2009, 35, 1425-1431. [CrossRef]

52. Zhang, P.; Guo, C.; Liu, Z.; Bernardo, A.; Ma, H.; Jiang, P.; Song, G.; Bai, G. Quantitative trait loci for Fusarium head blight resistance in wheat cultivars Yangmai 158 and Zhengmai 9023. Crop J. 2021, 9, 143-153. [CrossRef]

53. Gao, L.; Yan, X.; Li, X.; Guo, G.; Hu, Y.; Ma, W.; Yan, Y. Proteome analysis of wheat leaf under salt stress by two-dimensional difference gel electrophoresis (2D-DIGE). Phytochemistry 2011, 72, 1180-1191. [CrossRef]

54. Liu, T.G.; Peng, Y.L.; Chen, W.Q.; Zhang, Z.Y. First Detection of Virulence in Puccinia striiformis f. sp. tritici in China to Resistance Genes Yr24 (=Yr26) Present in Wheat Cultivar Chuanmai 42. Plant Dis. 2010, 94, 1163. [CrossRef] [PubMed]

55. Liu, B.; Liu, T.; Zhang, Z.; Jia, Q.; Wang, B.; Gao, L.; Peng, Y.; Jin, S.; Chen, W. Discovery and pathogenicity of CYR34, a new race of Puccinia striiformis f. sp. tritici in China. Acta Phytopathol. Sin. 2017, 47, 681-687. [CrossRef]

56. Wang, M.; Chen, X.; Xu, L.; Cheng, P.; Bockelman, H.E. Registration of 70 Common Spring Wheat Germplasm Lines Resistant to Stripe Rust. J. Plant Regist. 2012, 6, 104-110. [CrossRef]

57. Chen, W.; Wellings, C.; Chen, X.; Kang, Z.; Liu, T. Wheat stripe (yellow) rust caused by Puccinia striiformisf. sp. tritici. Mol. Plant Pathol. 2014, 15, 433-446. [CrossRef]

58. Line, R.F.; Qayoum, A. Virulence, Aggressiveness, Evolution, and Distribution of Races of Puccinia Striiformis (the Cause Of Stripe Rust of Wheat) in North America 1968-1987; US Department of Agriculture: Washington, DC, USA, 1992.

59. Peterson, R.F.; Campbell, A.B.; Hannah, A.E. A diagrammatic scale for estimating rust intensity on leaves and stems of cereals. Can. J. Res. 1948, 26, 496-500. [CrossRef]

60. Somers, D.J.; Isaac, P.; Edwards, K. A high-density microsatellite consensus map for bread wheat (Triticum aestivum L.). Theor. Appl. Genet. 2004, 109, 1105-1114. [CrossRef]

61. Rajapakse, S. GENETICS I Molecular Markers. Encycl. Rose Sci. 2003, 149, 334-341. [CrossRef]

62. Cuc, L.M.; Mace, E.S.; Crouch, J.H.; Quang, V.D.; Long, T.D.; Varshney, R.K. Isolation and characterization of novel microsatellite markers and their application for diversity assessment in cultivated groundnut (Arachis hypogaea). BMC Plant Biol. 2008, 8, 55. [CrossRef]

63. Bassam, B.J.; Caetano-Anollés, G.; Gresshoff, P.M. Fast and sensitive silver staining of DNA in polyacrylamide gels. Anal. Biochem. 1991, 196, 80-83. [CrossRef]

64. Liu, T.; Zhang, Z.; Liu, B.; Gao, L.; Peng, Y.; Chen, W. Detection of virulence to Yr26 and patho-genicity to Chinese commercial winter wheat cultivars at seedling stage. Acta Phytopathol. Sin. 2015, 45, 41-47. [CrossRef]

65. Liu, R.; Lu, J.; Zhou, M.; Zheng, S.; Liu, Z.; Zhang, C.; Du, M.; Wang, M.; Li, Y.; Wu, Y.; et al. Developing stripe rust resistant wheat (Triticum aestivum L.) lines with gene pyramiding strategy and marker-assisted selection. Genet. Resour. Crop Evol. 2020, 67, 381-391. [CrossRef]

66. Gautam, T.; Dhillon, G.; Saripalli, G.; Rakhi; Singh, V.P.; Prasad, P.; Kaur, S.; Chhuneja, P.; Sharma, P.K.; Balyan, H.S.; et al. Marker-assisted pyramiding of genes/QTL for grain quality and rust resistance in wheat (Triticum aestivum L.). Mol. Breed. 2020, 40, 49. [CrossRef]

67. Ren, M.; Xu, R. Molecular marker-assisted selection and identification of Guinong 19, a new wheat variety. Guizhou Agric. Sci. 2009, 37, 10-13.

68. Zhang, B.; Jia, Q.; Huang, J.; Cao, S.; Sun, Z.; Luo, H.; Wang, X.; Jin, S. Trends and toxicity analysis of new strains G22-9 and G22-14 in puccinia striiformis f. sp. Tritici. Acta Agric. Boreali Occident. Sin. 2015, 24, 125-130.

69. Li, W.; Song, G.; Li, J.; Li, Y.; Zhang, S.; Zhang, Z. Molecular detection of four pleiotropic disease resistance genes in wheat. J. Triticeae Crops. 2020, 40, 395-400.

70. Chen, F.; Mu, J.; Huang, C.; Liu, J.; Yao, J.; Meng, J. Comparison between pedigree and bulk method in wheat breeding. J. Jinling Inst. Technol. 2003. [CrossRef]

71. Liu, L.; Wang, M.N.; Feng, J.Y.; See, D.R.; Chao, S.M.; Chen, X.M. Combination of all-stage and high-temperature adult-plant resistance QTL confers high-level, durable resistance to stripe rust in winter wheat cultivar Madsen. Theor. Appl. Genet. 2018, 131, 1835-1849. [CrossRef]

72. Liu, L.; Yuan, C.Y.; Wang, M.N.; See, D.R.; Zemetra, R.S.; Chen, X.M. QTL analysis of durable stripe rust resistance in the North American winter wheat cultivar Skiles. Theor. Appl. Genet. 2019, 132, 1677-1691. [CrossRef] 